\title{
Questões político-criminais e processuais penais sobre a investigação criminal de chacinas protagonizadas por facções criminais nos presídios brasileiros
}

\author{
Political-criminal and criminal-procedural issues about the \\ criminal investigation of slaughters carried out by \\ criminal factions in Brazilian prisons
}

\section{Priscilla Placha Sá ${ }^{1}$}

Professora Adjunta da Pontifícia Universidade Católica do Paraná e da Universidade Federal do Paraná - Curitiba/PR

Doutora em Direito pela UFPR

priscillaplacha@terra.com.br

lattes.cnpq.br/5772348783494506

orcid.org/0000-0002-3697-4590

\begin{abstract}
Resumo: O objetivo do presente artigo é pontuar questões relacionadas com a investigação criminal de eventos ocorridos dentro das unidades prisionais envolvendo facções criminosas, sob dois aspectos: a questão político-criminal e o (des)interesse das autoridades públicas em investigar os fatos; e a questão processual penal envolvendo os meios de prova, tanto os tradicionais quanto os mais modernos. A metodologia utilizada, de forma majoritária, é a revisão bibliográfica, ainda que
\end{abstract}

1 Graduada em Direito, pela Faculdade de Direito de Curitiba (1998). Especialista em Direito Processual Penal - PUCPR (2002). Mestre em Direito, pela Pontifícia Universidade Católica do Paraná (2005). Doutora em Direito de Estado, pela Universidade Federal do Paraná (2013). Lecionou na Faculdade de Direito de Curitiba (2003-2004) e na Escola da Magistratura do Paraná (2008-2009). Atualmente é Professora Adjunta de Direito Penal da Pontifícia Universidade Católica do Paraná (desde 2002, na Graduação; 2009, na Pós-Graduação lato sensu). Diretora do NPJ da PUCPR (2007/2008). Professora Adjunta de Direito Penal da Universidade Federal do Paraná (desde 2010). Membro do Núcleo de Direito Processual Penal do PPGDUFPR (2010/2011) e Co-Coordenadora do Observatório da UFPR pela implementação da Defensoria Pública do Paraná (2011/2012). Vice-chefe do departamento de Direito Penal e Processual Penal da UFPR (2013-2016). Membro do Centro de Estudos de Segurança Pública e Direitos Humanos da UFPR (2009/2013). 
não exaustiva, pelos limites temporais e espaciais do presente texto. Em pontos específicos, notícias da grande mídia foram usadas para indicar a divulgação de dados e suposições, particularmente, sobre eventos mais recentes no intuito de demonstrar a percepção social sobre o tema. Este texto tem como orientação a matriz da sociologia para traçar um breve escorço histórico em relação ao surgimento e à instalação das facções criminosas nos presídios brasileiros, analisando a mutação do recurso aos motins (no marco das ocorrências de 2001 e 2006) para as chacinas (no marco dos eventos de 2013 e 2017). Já no campo da investigação criminal, as referências utilizadas para a tratativa são prioritariamente do campo processual penal, embora utilizados autores de ciências correlatas que estão atentos ao tema em discussão. As conclusões indicam a permanência de vicissitudes no campo da investigação criminal, no recorte proposto, especialmente, por questões de natureza científica, metodológica e operacional.

Palavras-chave: Chacinas; Facções criminosas; Investigação criminal; Apreensão de celulares.

ABSTRACT: The aim of this article is to discuss issues related to criminal investigation of events occurred inside prison units involving criminal groups, in two aspects: the political-criminal issue and the (dis)interest of the public authorities in investigating the facts, and the criminal procedural issue involving both traditional and modern means of proof. The methodology used, in a majority way, is the bibliographic revision, although not exhaustive, by the temporal and spatial limits of the present text. At specific points, it was used news from the major media to indicate the dissemination of data and assumptions, particularly about more recent events in order to demonstrate the social perception of the subject. It has as its orientation the matrix of sociology to draw a brief historical foreshortening regarding the emergence and the installation of criminal groups at Brazilian prisons, analyzing the mutation of the use of riots (within the context of 2001 and 2006) for the slaughters (at 2013 and 2017). At the field of criminal investigation, the references used for the treatment are primarily of the criminal procedural, although it was used authors of related sciences that are attentive to the subject under discussion. The conclusions indicate the continuity of weakness at the field of criminal investigation, in the proposed theme, especially, due to scientific, methodological and operational issues.

KeY-words: Slaughter; Criminal groups; Criminal investigation; Apprehension of cellphones. 
SumÁRIO: Introdução; 1. Do protagonismo do Primeiro Comando da Capital nas rebeliões prisionais: breve escorço histórico; 1.1. As rebeliões de 2001 e 2006; 1.2. Das rebeliões às chacinas de 2013 e de 2017; 2. A afirmação do poder e o uso das tecnologias por facções criminosas; 2.1. Um histórico de práticas violentas e cruéis; 2.2. A utilização de dispositivos tecnológicos, redes e mídias sociais e aplicativos como forma de afirmação de poder; 3 . As vicissitudes da investigação criminal nos casos de rebeliões e chacinas ocorridas no sistema carcerário brasileiro; 3.1. Uma nota de natureza político-criminal sobre as investigações das chacinas de 2017; 3.2. O recurso aos meios tradicionais de investigação criminal; 3.3. O recurso aos novos meios de investigação criminal; Considerações finais; Referências Bibliográficas.

\section{INTRODUÇÃo}

A Lei de Execução Penal (Lei no $7.210 / 84$ ) assegura que dentre os direitos das pessoas privadas de liberdade está o de se comunicar com o mundo exterior, por meio de correspondência escrita, leitura e outros meios de informação que "não comprometam a moral e os bons costumes" (art. 41, LEP), cujo objetivo parece pretender garantir a permanência de laços externos entre as pessoas detidas e suas famílias. A legislação em referência foi aprovada no ano de 1984, após os trabalhos de uma Comissão Parlamentar de Inquérito, cujo relatório foi aprovado em 1976, conforme se vê de sua Exposição de Motivos (especialmente, os itens 170 e 171). Nesse momento já estavam presentes graves violações aos direitos das pessoas privadas de liberdade, mesmo quando as temáticas do crime organizado e da superlotação carcerária não eram emergentes, estando em evidência a questão dos presos políticos ${ }^{2}$.

A contraposição às sevícias e à violência institucional contra as pessoas privadas de liberdade (praticadas desde há muito e confirmadas na CPI antes indicada) encontraria - anos depois - conforto na proposta

2 RUDNICKI, Dani; SOUZA, Mônica Franco de. Em busca de uma política pública para os presídios brasileiros. As CPIS do sistema penitenciário de 1976 e 1993. Revista de Informação Legislativa. Brasília, a. 47, n. 186, abr./ jun. 2010, p. 110. 
discursiva daquele que parece ter se tornado o maior ou um dos maiores grupos organizados ${ }^{3}$ dentro dos presídios: o Primeiro Comando da Capital (PCC). Essa bandeira lhe rendeu a imagem interna de que se coloca como uma fraternidade de apoio e de atenção às pessoas presas e suas famílias, não sem estabelecer a disciplina do comando, cuja imposição e configuração, além de seu regramento, não dispensa o uso de violência. ${ }^{4}$

A violência aqui será considerada a um só tempo como adjetivo e como elemento estruturante das relações sociais no Brasil ${ }^{5}$. No caso dessas facções, a violência aparece tanto para estabelecer uma hegemonia no âmbito prisional ${ }^{6}$, quanto para exportar suas práticas por mensagens, pelos mais variados meios, especialmente por meio de smartphones e seus aplicativos.

O locus do sistema carcerário ${ }^{7}$, historicamente, propicia a troca de favores e a adoção de práticas regionalizadas e idiossincráticas, por parte de seus dirigentes, estabelecidas em regramentos, muitas vezes,

3 Não se tem encontrado termo único para tratar dessa figura, conforme elucidam Lourenço e Almeida, sendo mais recorrentes o uso dos termos "facções" e comandos": LOURENÇO, Luiz Claudio; ALMEIDA, Odilza Lines de. "Quem mantém a ordem, quem cria desordem”: gangues prisionais na Bahia. Tempo social - Revista de Sociologia da USP. São Paulo, v. 25, n. 1, jun. 2013. p. 38-39.

4 Sobre a utilização da expressão Disciplina do Comando, suas implicações e o extenso rol de regras que passam a reger os afiliados: DIAS, Camila Caldeira Nunes. A disciplina do PCC: a importância do (auto)controle na sociabilidade prisional. Revista Brasileira de Ciências Criminais, v. 18, n. 86, set./out. 2010. p. 401-404. Vale ressaltar a observação da autora de que tal Disciplina não visa apenas comportamentos negativos ou proibitivos, mas também "visa regular o comportamento das pessoas em seus mais ínfimos gestos, palavras e atitudes, na conformação de uma identidade pautada por valores próprios do mundo do crime e que é definida por vários presos entrevistados como sendo o lado certo da vida errada." (DIAS, Camila Caldeira Nunes. A disciplina do PCC: a importância do (auto)controle na sociabilidade prisional. p. 404).

5 Sobre a utilização da violência como mediadora das relações sociais no Brasil, conferir: BATISTA, Vera Malaguti. O medo e o método. Instituto Carioca de Criminologia. Discursos Sediciosos: Crime, Direito e Sociedade. Rio de Janeiro: Freitas Bastos Editora, ano 5, n. 9 e 10, p. 187-195, $1^{\circ}$ e $2^{\circ}$ semestres, 2000.

6 Na linha do que já fora ponderado, conferir: DIAS, Camila Caldeira Nunes. A disciplina do PCC: a importância do (auto)controle na sociabilidade prisional, p. 407.

7 Terminologicamente, para os fins desse artigo, consideramos como "sistema carcerário" todo o locus que priva pessoas de sua liberdade, ou seja, delegacias de polícia, centros de detenção provisória e penitenciárias. 
não escritos e por isso de difícil controle externo. Isso se dá a partir da própria Lei de Execução Penal, que permite que a administração penitenciária conceda benesses a quem esteja em privação de liberdade ${ }^{8}$.

Esse fato não deixa de constituir uma liberalidade das administrações, por uma série de fatores, mas sobretudo porque a precariedade das condições ensejará escolhas seletivas e, eventualmente, arbitrárias para sujeitos que se encontram na mesma situação. Por exemplo, ausente critério legal, como a direção de uma penitenciária, satisfeitos os demais requisitos, escolhe quem serão os internos que ocuparão os postos de trabalho, considerando inexistir número suficiente para os que estão em igual condição? Isso potencializa tensões não apenas entre os detentos e as direções, mas refunda questões internas de poder de um determinado "grupo organizado" em detrimento de outro.

Além disso, atualmente, não parece existir dúvidas de que tais "grupos organizados" têm teias externas muito sólidas'; as quais mantêm e espraiam o exercício da atividade criminal, especialmente, o comércio de drogas ilícitas, com ramificações para roubos a banco e tráfico de armas, dentre outros.

O imagético e a performance desse grupo - assim como das demais organizações do extrato social - utilizam os mecanismos à disposição, seja para se impor, seja para deflagrar e divulgar suas práticas. Os bilhetes e recados foram substituídos por outros, até chegarem aos smartphones, redes e mídias sociais e seus aplicativos, como o WhatsApp, cuja utilização restou evidenciada pela grande mídia nas chacinas ocorridas no mês de janeiro de 2017, das quais resultaram mais de 130 mortes, no Norte e Nordeste do país.

8 Camila Nunes Caldeira Dias, acerca da existência e criação de regras no âmbito do sistema carcerário, pondera que a instalação da Disciplina do Comando não constitui, por si, nenhuma novidade: "O longo confinamento, a convivência forçada, o reduzido espaço destinado à vivência social, bem como as experiências mais particulares - se é que elas são possíveis - tornam imprescindível a criação de normas que visem regular o comportamento do preso de forma que a vida se torne minimamente suportável na prisão.” (DIAS, Camila Caldeira Nunes. A disciplina do PCC: a importância do (auto)controle na sociabilidade prisional, p. 399).

9 ADORNO, Sérgio; SALLA, Fernando. Criminalidade organizada nas prisões e os ataques do PCC. Estudos Avançados, São Paulo, v. 21, n. 61, dez. 2007. p. 09. 
Eventos conhecidos, inclusive, no âmbito internacional, como os episódios de Urso Branco e Carandiru, indicam esse histórico de violência dentro dos presídios, nos quais as discussões sobre autoria, para fins de responsabilização encontram pontos de fragilidade desde a investigação preliminar.

Encerradas as rebeliões e as chacinas, com as apreensões de centenas de celulares, dentre outros objetos, como no caso de 2017 , remanesce a pergunta sobre o empenho das autoridades públicas em identificar as circunstâncias em que se desencadearam e ocorreram tais fatos, sobretudo, os crimes de homicídio, além da possibilidade ou não de utilizar o conteúdo e os dados armazenados em referidos celulares para apuração e responsabilização.

Tal indagação - sobre a investigação criminal e a coleta de elementos probatórios - é a proposta do presente texto. Ele tem como ponto de partida uma breve análise da presença do Primeiro Comando da Capital e seu protagonismo em rebeliões e chacinas, a partir de considerações do âmbito da sociologia. Posteriormente, segue na análise da investigação criminal, primeiro numa perspectiva político-criminal (acerca do interesse das autoridades constituídas em apurar tais crimes), e num segundo momento, sob o ponto de vista do direito processual penal (quanto às dificuldades em realizar tal investigação e coletar provas para subsidiar futura ação penal) em face do histórico de casos que envolvem o sistema carcerário brasileiro.

\section{Do protagonismo do Primeiro Comando da Capital nas REBELIÕES PRISIONAIS: BREVE ESCORÇO HISTÓRICO}

Entre a deificação e a demonização do Primeiro Comando da Capital aparece um histórico que o faz ser nominado ora como "facção" ora "comando", devendo registrar-se que, particularmente ante o advento da Lei 12.850/2013, também poderia ser referido como "organização criminosa", a partir de uma concepção de tipicidade ${ }^{10}$. Nesse texto por

10 A expressão “organização criminosa” ou “crime organizado" encontra, mesmo com a edição da Lei 12.850/2013, que trouxe uma definição típica, uma miríade de análises a partir da ciência conjunta do direito penal que não se 
uma opção teórica iremos chamar essa e outras agremiações dentro dos presídios como "facções", numa perspectiva sociológica, embora constitua - em princípio - na linha dogmática uma "organização criminosa".

As pesquisas de Sérgio Adorno e Fernando Salla ${ }^{11}$, como também de Camila Caldeira Nunes Dias ${ }^{12}$ e de Cesar Caldeira ${ }^{13}$ revelam que se trata de uma organização detentora de poder e que em nome desse poder vale-se, também, de práticas violentas. Tais práticas, não raro, remetem a tempos obscuros como a ditadura civil-militar ${ }^{14}$, em que tais

restringem ao seu conceito legal. Por conta da existência desse fenômeno - no âmbito mundial, como realidade e ante a Convenção de Palermo - setores da doutrina já vinham debatendo essa categoria. Por exemplo: DIAS, Jorge de Figueiredo. A criminalidade organizada: do fenómeno ao conceito jurídico-penal. Revista Brasileira de Ciências Criminais, v. 16, n. 71, p. 11-30, mar./abr. 2008. Sob a perspectiva criminológica: SANTOS, Juarez Cirino dos. Crime Organizado. Disponível em: <http://icpc.org.br/wp-content/uploads/2013/01/crime_organizado.pdf>. Com a edição da Lei 12.850/2013, tem-se os comentários acerca de sua definição legal formulados por: BITENCOURT, Cezar Roberto; BUSATO, Paulo César. Comentários à Lei de Organização Criminosa: Lei n. 12.850/2013. São Paulo: Saraiva, 2014. p. 1923; GRECO FILHO, Vicente. Comentários à Lei de Organização Criminosa: Lei n. 12.850/13. São Paulo: Saraiva, 2014. p. 20-21. A caracterização dessas agremiações, inclusive, com um formato a partir de um novo tempo, enfrentando a questão do "crime organizado" como algo que não está apartado do contexto social, tampouco que deixa de compartilhar da estrutura macro, inserindo-se a um só tempo no contexto de redes e no de uma nova sociologia econômica é o trabalho de Edmílson Lopes Júnior (As redes sociais do crime organizado: a perspectiva da nova sociologia econômica. Revista brasileira de Ciências Sociais, São Paulo, v. 24, n. 69, p. 53-68, fev. 2009). Especificamente, sobre o enraizamento da criminalidade organizada e seus contornos muito peculiares dentro das prisões brasileiras, que é o objeto desse texto, conferir: ADORNO, Sérgio; SALLA, Fernando. Criminalidade organizada nas prisões e os ataques do PCC. p. 14; DIAS, Camila Caldeira Nunes. A disciplina do PCC: a importância do (auto)controle na sociabilidade prisional. p. 395-396.

11 ADORNO, Sérgio; SALLA, Fernando. Criminalidade organizada nas prisões e os ataques do PCC. Como também o trabalho de: MESQUITA NETO, Paulo de; SALLA, Fernando. Uma análise da crise de Segurança Pública de maio de 2006. Revista Brasileira de Ciência Criminais, v. 15, n. 68, p. 309-351, set./ out. 2007.

12 DIAS, Camila Caldeira Nunes. A disciplina do PCC: a importância do (auto) controle na sociabilidade prisional.

13 CALDEIRA, Cesar. A política do cárcere duro: Bangu 1. São Paulo em Perspectiva, São Paulo, v. 18, n. 1, p. 87-102, mar. 2004.

14 Inclusive há controvérsias sobre os motivos em que foi aprovada a realização da CPI de 1976, antes indicada: cf. RUDNICKI, Dani; SOUZA, Mônica Franco 
organizações podem ter encontrado ambiente fértil para seu surgimento, associadas posteriormente à violência do embate cotidiano da guerra às drogas em que emerge a violência policial ou entre grupos rivais ${ }^{15}$.

A construção do status de "grupo organizado" ou "facção criminosa" - mesmo com contornos distintos nas visões de Camila Caldeira Nunes Dias ${ }^{16}$ e Edmilson Lopes Junior ${ }^{17}$ - parece utilizar ferramentas típicas e protagonizar ações violentas que demonstram poder para impor respeito e medo aos demais presos, como também à própria administração e às autoridades constituídas.

de. Em busca de uma política pública para os presídios brasileiros. As CPIS do sistema penitenciário de 1976 e 1993. p. 108-109.

15 Sobre o possível surgimento da "facção" conhecida como "Falange Vermelha" e sua mutação ao longo de cinco décadas, até o envolvimento com o tráfico de drogas: Quase dois irmãos. Direção e produção Lúcia Murat. Brasil. 2004. Drama. DVD (102 min). Colorido. Já sobre o estabelecimento de uma hegemonia, por parte do Primeiro Comando da Capital: Salve Geral. Direção Sérgio Rezende e Patrícia Andrade. Produção Joaquim Vaz de Carvalho. Brasil. 2009. Drama/Policial. DVD (119 min). Colorido. No que concerne à disputa entre "traficantes" e "policiais", por conta do controle territorial de favelas no Rio de Janeiro: Tropa de Elite: missão dada é missão cumprida. Direção José Padilha. Produção Marcos Prado e José Padilha. Coprodução Eliana Soarez e James Darcy. Brasil. 2007. Ação. DVD (116 min.). Colorido. Tropa de Elite 2: o inimigo agora é outro. Direção José Padilha. Produção Marcos Prado e José Padilha. Coprodução Wagner Moura e Bráulio Mantovani. Brasil. 2010. Ação. Blu-ray Disc (115 min.). Colorido. A atividade de outras organizações criminosas nos presídios cariocas, como o Comando Vermelho, por exemplo, não é ignorada pela presente análise, mas não serão objeto de atenção, pois ao longo do período compreendido (2001-2017) o Primeiro Comando da Capital assumiu lugar de destaque. Sobre a atuação do Comando Vermelho e algumas afinidades com o Primeiro Comando da Capital, conferir: CALDEIRA, Cesar. A política do cárcere duro: Bangu 1. p. 89. Ainda sobre as rebeliões, também, no Rio de Janeiro, ver: SALLA, Fernando. As rebeliões nas prisões: novos significados a partir da experiência brasileira. Sociologias, Porto Alegre, n. 16, dez. 2006. p. 298-300.

16 A autora aborda a constituição das relações de poder estabelecidas pelo PCC, em especial, ao confisco da prerrogativa da força pelos detentos por meio de decisão individual: DIAS, Camila Caldeira Nunes. A disciplina do PCC: a importância do (auto)controle na sociabilidade prisional. p. 407-408.

17 O autor propõe uma inversão analítica do fenômeno do crime organizado e redes sociais, a partir de argumentos de setor de análise econômica: LOPES JUNIOR, Edmílson. As redes sociais do crime organizado: a perspectiva da nova sociologia econômica. p. 62-65. 


\subsection{As RebeLIões de 2001 e 2006}

A Lei de Execução Penal aprovada em 1984 parece não ter rompido o ciclo de violência que se agravava no sistema carcerário nacional, durante o período da ditadura civil-militar, e que pouco a pouco fez eclodir as violações a que as pessoas privadas de liberdade se encontravam submetidas no Brasil.

As rebeliões, com mortes ou não, ainda que possam se constituir como episódios de crise no sistema carcerário, acabam por silenciar as condições subumanas em que os presos se encontram. ${ }^{18}$ Ainda que, vez ou outra, alguns desses episódios suscitem certa comoção social ou movimentação política, logo voltam ao seu ponto originário de esquecimento. No entanto, o envolvimento das facções criminosas e até mesmo a interferência dita hegemônica de uma única dessas facções ganha relevo nas rebeliões ocorridas a partir de 2001.

Num ambiente murado, em que o descontrole sobre as agências de repressão transcendeu as décadas de 60 e 70, o Primeiro Comando da Capital encontrou ambiente propício para nascer e afirmar-se. Criado no ano de 1993, no Anexo da Casa de Taubaté, começaria a se expandir silenciosa e gradativamente como também se repetiriam com mais frequência e com mais organicidade as rebeliões. Algumas pistas tais como: a forma de ocorrência das rebeliões, a pauta de reivindicação, o apoio externo e a força corruptora davam mostras de que algo estava mudando no âmbito carcerário. ${ }^{19}$

As rebeliões não eram um dado novo na história mais recente do sistema carcerário brasileiro ${ }^{20}$, mas era novo o formato que começava a ser delineado, evidenciando num primeiro momento a presença e a participação ativa de facções criminosas em sua deflagração ${ }^{21}$, e num

18 CALDEIRA, Cesar. A política do cárcere duro: Bangu 1. p. 87.

19 DIAS, Camila Caldeira Nunes. A disciplina do PCC: a importância do (auto) controle na sociabilidade prisional. p. 397

20 Considerando o marco temporal pós-88, no qual se evidencia um aumento gradativo de início e exponencial pouco tempo depois.

21 Aqui são novamente referidos os trabalhos de: CALDEIRA, Cesar. A política do cárcere duro: Bangu 1; ADORNO, Sérgio; SALLA, Fernando. Criminalidade organizada nas prisões e os ataques do PCC e DIAS, Camila Caldeira Nunes. A disciplina do PCC: a importância do (auto)controle na sociabilidade prisional. A versão mais completa e aprofundada da análise de DIAS encon- 
segundo momento a utilização de mecanismos e dispositivos tecnológicos, como celulares para a comunicação e a divulgação de suas práticas.

O primeiro episódio aqui referido (o de 2001) é indicado como sendo o momento em que as rebeliões deflagradas no âmbito do sistema carcerário paulistano deixam entrever a disputa de poder entre autoridade constituída e facção. A oposição entre as autoridades constituídas que determinaram a separação de lideranças do Primeiro Comando da Capital e a discordância da facção parece ter sido o seu estopim. Essas rebeliões seriam a resposta à interferência das autoridades no modo da organização de tais grupos; diversamente, por exemplo, do que se tinha nos presídios cariocas, onde as lideranças é que decidiam acerca da conformação interna e de sua divisão e organização ${ }^{22}$.

O cenário potencializado por um histórico de violações de direitos, associado ao hiperencarceramento ${ }^{23}$, que já começava a dar mostras das consequências desastrosas, ganha o expoente das megarrebeliões e coloca o Primeiro Comando da Capital numa posição de vantagem e de prestígio, inclusive, de forma simbólica ao hastear uma bandeira branca ${ }^{24}$.

A deflagração desses fatos interfere também no âmbito externo, tanto ao evidenciar sua existência, quanto ao usar meios violentos para se estabelecer, embora há muito já tivesse sequestrado a prerrogativa de os próprios internos reivindicarem o dispositivo da violência por sua decisão individual e para sua autodefesa ${ }^{25}$.

Posteriormente, no ano de 2006, no mês de maio, ocorreram rebeliões em 73 presídios. Mas também houve graves consequências

tra-se em sua tese de doutoramento, na qual, inclusive, são apresentados os resultados de coleta empírica de entrevistas com presos que fariam parte do PCC: Da pulverização ao monopólio da violência: expansão e consolidação do Primeiro Comando da Capital (PCC) no sistema carcerário paulista. 386 f. Tese (Doutorado em Sociologia) - Faculdade de Filosofia, Letras e Ciências Humanas, Universidade de São Paulo, São Paulo, 2011.

CALDEIRA, Cesar. A política do cárcere duro: Bangu 1. p. 89.

PASTANA, Débora. Estado punitivo e encarceramento em massa: retratos do Brasil atual. Revista Brasileira de Ciências Criminais, v. 17, n. 77, mar./abr. 2009. p. 315-318.

24 DIAS, Camila Caldeira Nunes. A disciplina do PCC: a importância do (auto) controle na sociabilidade prisional. p. 398.

25 DIAS, Camila Caldeira Nunes. A disciplina do PCC: a importância do (auto) controle na sociabilidade prisional. p. 398. 
externas, com distensão para os meses seguintes: 439 mortes (com laudos de necropsia elaborados por 23 Institutos Médico-Legais), além de ataques contra civis, prédios privados, postos policiais e incêndios de carros e ônibus, dentre outros eventos que culminaram na paralisação temporária da maior cidade da América Latina ${ }^{26}$.

A discussão das causas dessas megarrebeliões de 2006 encontra profusa publicação na imprensa ora apontando para a crise da segurança pública, ora para as condições de vida nas prisões, com apreciação heterogênea da população e dos especialistas ${ }^{27}$. A atuação do Primeiro Comando da Capital - pelo recorrente uso da violência, particularmente, por meio de teias simbólicas - angariou centenas de adeptos que deram conta de disseminar a sua ideologia e afirmar uma hegemonia no sistema carcerário brasileiro ${ }^{28}$.

Todavia, essa pretensa posição dominante num ambiente propício a formações de grupos suscita contraposições de poder com a utilização de mecanismos ao menos similares. A Comissão Parlamentar de Inquérito sobre o sistema carcerário instalada em 2008 afirmou existirem mais de 30 grupos organizados nos presídios brasileiros ${ }^{29}$, cuja disputa por espaço e por poder renderia ainda muitas mortes no sistema carcerário e fora dele.

\subsection{DAS ReBelIÕES Às CHACINAS DE 2013 E DE 2017}

A característica de uma rebelião normalmente está associada a uma demanda, a uma pauta. Aliás, do histórico antes relatado, o próprio surgimento do Primeiro Comando da Capital era autorreferente por

26 ADORNO, Sérgio; SALLA, Fernando. Criminalidade organizada nas prisões e os ataques do PCC. Estudos Avançados, São Paulo, v. 21, n. 61, dez. 2007. p. 7; MESQUITA NETO, Paulo de; SALLA, Fernando. Uma análise da crise de Segurança Pública de maio de 2006. Revista Brasileira de Ciência Criminais. p. 313-318.

27 ADORNO, Sérgio; SALLA, Fernando. Criminalidade organizada nas prisões e os ataques do PCC. p. 8; MESQUITA NETO, Paulo de; SALLA, Fernando. Uma análise da crise de Segurança Pública de maio de 2006. p. 319-328.

28 DIAS, Camila Caldeira Nunes. A disciplina do PCC: a importância do (auto) controle na sociabilidade prisional. p. 407.

29 LOURENÇO, Luiz Claudio; ALMEIDA, Odilza Lines de. "Quem mantém a ordem, quem cria desordem”: gangues prisionais na Bahia. p. 37. 
isso, especialmente, por se contrapor à administração penitenciária e às autoridades constituídas, sobretudo, contra suas práticas de violência institucional. Os episódios de 2013 e 2017, entretanto, ganham contornos distintos.

Em menos de dez anos depois das megarrebeliões de 2006, em São Paulo, as atenções se voltariam para o Nordeste do País. Em especial, para o estado do Maranhão onde fica o Complexo Penitenciário de Pedrinhas. A trágica situação do estado maranhense como um todo viu-se refletida no que acontecia dentro de seus presídios, quando em dezembro de 2013, 62 presos foram assassinados, pela disputa de duas facções para obter o controle interno da unidade prisional ${ }^{30}$.

O Complexo Penitenciário foi "palco de cenas de barbárie, como a decapitação de presos, sevícias e um sem-número de violações de direitos fundamentais" ${ }^{31}$. Houve, também, repercussões externas após "um circo de horrores dentro da cadeia, a violência transborda e atinge a própria população, com incêndios em ônibus, mortos e feridos" ${ }^{\text {"2 }}$. Nublando o fato de que naquele ano já haviam morrido mais de 60 pessoas em tal unidade, ou que tal presídio já acomodara uma rebelião em 2010, a maior e mais violenta acontecida no Estado até então ${ }^{33}$. As autoridades constituídas e a administração penitenciária pareciam ter certa inércia em não adotar medidas, mesmo diante do recebimento de verbas públicas e de pedidos de intervenção federal no estado em face da crise instalada ${ }^{34}$.

A grande mídia atribuiu o episódio à disputa entre as facções Primeiro Comando do Maranhão e Bonde dos 40 pelo controle da unidade prisional; a primeira teria sido formada sob a inspiração do Primeiro Comando da Capital, já a segunda, com membros mais jovens, surge em sua oposição. Ainda, segundo a mídia, as investigações da polí-

30 CEGUEIRA deliberada estatal. Editorial. Boletim IBCCRIM, n. 255, fev. 2014.

31 PPPs e terceirizações nos presídios: a indústria do sofrimento e da punição. Editorial. Boletim IBCCRIM, n. 279, fev. 2016.

32 Cegueira deliberada estatal. Editorial. Boletim IBCCRIM.

33 Fugitivo do PSL 3 foi líder da rebelião mais violenta do Maranhão. Disponível em: <http:/g1.globo.com/ma/maranhao/noticia/2015/04/fugitivo-do-ps1-3-foi-lider-de-rebeliao-mais-violenta-do-maranhao.html>. Acesso em: 09 abr. 2017.

34 Cegueira deliberada estatal. Editorial. Boletim IBCCRIM. 
cia civil informavam que havia pessoas ligadas ao PCC naquela unidade prisional ${ }^{35}$. Outro segmento da mídia aponta que os fatos decorreram da disputa de quatro facções, além das duas já citadas, outros dois grupos menores também teriam representação: Anjos da Morte (mais temidos pelas práticas selvagens) e Mensageiros do Inferno ${ }^{36}$.

As disputas de poder entre facções para a obtenção do monopólio prisional ensejariam outros episódios poucos anos depois, na mesma linha da utilização da barbárie antes enunciada: as chacinas ocorridas no Complexo Penitenciário Anísio Jobim (COMPAJ), no estado do Amazonas, e no Presídio de Alcaçuz, no Rio Grande do Norte $^{37}$, em janeiro de 2017, sendo vários os casos de dilacerações, esquartejamentos, entre outras violências.

Também, com informações coletadas na mídia eletrônica, os fatos teriam decorrido da disputa pelo controle das unidades prisio-

35 Cf. Disputa do tráfico e influência do PCC guiam facções no Maranhã. Disponível em: <http://ultimosegundo.ig.com.br/brasil/ma/2014-01-13/ disputa-do-trafico-e-influencia-do-pcc-guiam-faccoes-no-maranhao.html $>$. Acesso em: 09 abr. 2017.

36 Cf. Presídio que teve detentos decapitados é disputado por 4 facções no MA. Disponível em: <http://www1.folha.uol.com.br/cotidiano/2014/01/ 1400021-presidio-que-teve-detentos-decapitados-e-disputado-por-4-faccoes-no-ma.shtml>. Acesso em: 09 abr. 2017.

37 Torna-se difícil precisar o número exato de mortes, ocorridas nesses eventos. Em alguns casos, o reconhecimento e liberação dos corpos foi bastante demorado, pois os presos foram decapitados, entre outras práticas violentas. O site de notícias G1, no dia 16 de janeiro de 2017, consolidou, até a data da postagem, o número de 133 mortos em unidades prisionais (Mortes em presídios do país em 2017 já superam o massacre do Carandiru. G1, 16 jan. 2017. Disponível em: <http://g1.globo.com/bom-dia-brasil/noticia/2017/01/ mortes-em-presidios-do-pais-em-2017-ja-superam-o-massacre-do-carandiru. html>. Acesso em: 29 jan. 2017). Já o site da Carta Capital, lista as unidades e a quantidade de pessoas mortas em cada uma, dentre as ocorrências nos seguintes estados: Amazonas, Paraíba, Roraima, Alagoas, São Paulo, Paraná, Santa Catarina e Rio Grande do Norte, sendo que o maior número de mortos, de forma isolada, tem lugar em Manaus-AM (no COMPAJ) e em Nísia Floresta-RN (no Presídio de Alcaçuz) (Carnificina em presídios deixou mais de 130 mortos neste ano. Carta Capital, 16 jan. 2017. Disponível em: <http:// www.cartacapital.com.br/sociedade/carnificina-em-presidios-deixou-mais-de-130-mortos-neste-ano>. Acesso em: 29 jan. 2017). Luís Carlos Valois refere, só no caso do Complexo Anísio Jobim, a ocorrência de 56 mortes (Espólio de medo, terror e desesperança. Boletim IBCCRIM, n. 291, fev. 2017.). 
nais, cujo protagonismo volta-se ao Primeiro Comado da Capital agora em oposição à Família do Norte. O mote, da mesma maneira que em Pedrinhas e no histórico de casos, estaria associado ao controle do comércio de drogas, inclusive fora das prisões ${ }^{38}$. Ao primeiro evento, ocorrido em Manaus, sucede o de Rio Grande do Norte, como resposta.

A mutação de rebelião para chacina, em que não há demanda nem reivindicação, aparece na observação do juiz da execução penal de Manaus, Luís Carlos Valois, sobre as chacinas de janeiro de 2017:

Não há como classificar aquilo de rebelião, pois não havia exigências. Os presos não queriam nada antes da rebelião, melhora da comida, troca de diretor, agilização de processos, como é comum na maioria das rebeliões. A carnificina era o motivo, a revolta era o meio para a carnificina. ${ }^{39}$

Percebe-se, assim, a modificação tanto do mote quanto da forma; a demanda e a pauta foram substituídas pela disputa de poder e pelo controle prisional, tendo como pano de fundo o comércio de drogas.

\section{A AFIRMAÇÃo do PODER E O USO DAS TECNOLOGIAS POR FACÇÕES CRIMINOSAS}

Com esse breve cenário, pode-se afirmar a utilização de práticas violentas pelas próprias facções para se contrapor tanto à violência institucional, quanto a outros grupos e controlar unidades carcerárias. Valem-se do expediente que pretendem questionar. As cenas divulgadas pelos próprios detentos dão conta de práticas terrificantes, cruéis e até mesmo canibais em que o outro não é poupado e sim usado como objeto da demonstração de poder.

A percepção social dos fatos violentos, entretanto, não está fixada apenas no cenário brasileiro quando se fala de fatos envolvendo facções e sua vinculação com o tráfico de drogas. A onipresença da violência orienta-se por novos paradigmas que envolvem, também, distintas formas de

38 Massacre em presídio em Manaus deixa 56 detentos mortos. Disponível em: <http:// brasil.elpais.com/brasil/2017/01/02/politica/1483358892_477027.html>.

39 VALOIS, Luís Carlos. Espólio de medo, terror e desesperança. 
comunicação associadas, por sua vez, com fenômenos que se constituem como ameaças a partir da perspectiva da "criminalidade organizada", nas quais se incluem o terrorismo e o tráfico de drogas, com especial desta$q^{4} \mathrm{e}^{40}$. Essa violência não está barrada pelos muros da prisão.

\subsection{UM HISTÓRICO DE PRÁTICAS VIOLENTAS E CRUÉIS}

No âmbito do sistema prisional, conforme delineado, o argumento de pretensão de legitimidade como anteparo e resistência à prática institucional violenta, agora parece estar orientado a construir uma hegemonia, ao custo de uma violência em seu formato primitivo e selvagem. Embora usada de forma escancarada nos eventos de 2013 e 2017, havia pistas de sua expansão desde as rebeliões nos presídios paulistas ocorridas em $2001^{41}$.

O PCC construiu os pilares de sustentação de seu poder a partir de um repertório simbólico remetido à ideia de luta entre oprimidos (presos) e opressores (estado e sociedade) e do enredamento da população carcerária numa narrativa social marcada pela injustiça, pela violência e pela miséria, cuja possibilidade de superação é dada justamente pela união de todos em torno da organização. A violência foi, inegavelmente, um importante instrumento de imposição do domínio do PCC no sistema prisional, mas ela não pode ser desmembrada de sua contrapartida simbólica, que reforçava o poder da facção e, ao mesmo tempo, legitimava as execuções realizadas em nome de um ideal de união e da formação de uma irmandade. ${ }^{42}$

Isso pode indicar uma diferença entre as megarrebeliões de 2001 e 2006, nos presídios paulistas, quando se falava em contraposição à violência institucional, e as chacinas ocorridas no Presídio de

40 HASSEMER, Winfried. Persona, Mundo y Responsabilidad. Bases para una teoría de la imputación em Derecho Penal. Valencia: Tirant lo Blanch, 1999. p. 80-81.

41 SALLA, Fernando. As rebeliões nas prisões: novos significados a partir da experiência brasileira. p. 276-277.

42 DIAS, Camila Caldeira Nunes. A disciplina do PCC: a importância do (auto) controle na sociabilidade prisional. p. 398-399. 
Pedrinhas, no ano de 2013, e no marco mais recente de janeiro de 2017, em especial, no Complexo Anísio Jobim, em Manaus-AM, e no Presídio de Alcaçuz, na Grande Natal-RN, nos quais haveria disputas entre os grupos rivais Primeiro Comando da Capital e Família do Norte (FDN).

\subsection{A UTILIZAÇÃO DE DISPOSITIVOS TECNOLÓGICOS, REDES E MÍDIAS SOCIAIS E APLICATIVOS COMO FORMA DE AFIRMAÇÃO DE PODER}

Embora literalmente antigas e precárias as estruturas da prisão e, em alguns casos, as políticas dirigentes, os tempos são novos, como também o são os recursos e as tecnologias que os regem. Práticas rudimentares em torno dos "grupos organizados" servem, inclusive, para separar o ingresso de presos, determinar os horários de banho de sol e os dias de visita. E os "grupos organizados" sabem disso. Como também estão apropriados das formas de comunicação em rede, dos efeitos que a contemplação da imagem ocupa no momento atual e a reafirmação do monopólio de práticas violentas como forma de estabelecer e manter o poder, na medida em que os muros da prisão não exercem a contenção pretendida pelo imaginário social de um mundo à parte.

Esse sistema foi colocado à prova justamente durante as ondas de ataque, mostrando que a organização estava capacitada para controlar o andamento simultâneo de inúmeras rebeliões; para atacar alvos distintos sem uma lógica predeterminada e com elevada dose de surpresa; para estar em qualquer lugar e desaparecer de imediato; para expedir ordens e, logo depois, determinar a suspensão das ações; para negociar com altas autoridades do estado. ${ }^{43}$

Mas a pedagogia da crueldade, então, usada nos vídeos feitos e divulgados pelos próprios detentos, tem elementos que demonstram, além de um completo desprezo à condição do outro e da sua subjetividade, a constituição de uma imagem de poder e do uso da violência como forma de sua difusão e de sua manutenção. Essa tecnologia é própria das instituições estabelecidas, cujas permanências vêm do modelo panópti-

43 ADORNO, Sérgio; SALLA, Fernando. Criminalidade organizada nas prisões e os ataques do PCC. p. 9. 
co descrito por Michel Foucault ${ }^{44}$, que não é só arquitetura, mas funciona "como máquina maravilhosa que, a partir dos desejos mais diversos, fabrica efeitos homogêneos de poder" ${ }^{45}$. No caso brasileiro, transcenderam a ditadura civil-militar das décadas de 60 e $70^{46}$.

Os eventos de janeiro de 2017 parecem confirmar isso. A narrativa inicial de Bruno Paes Manso ${ }^{47}$ sobre as chacinas nos presídios é nauseante e dá conta de que recebeu de um ex-presidiário os vídeos feitos e protagonizados por detentos, por meio do WhatsApp.

Se nas megarrebeliões de 2006, foram apreendidos com os internos de algumas prisões paulistas, além de celulares, telefones com ramais, rádios e computadores ${ }^{48}$, a partir da chacina acontecida em Pedrinhas - MA, em dezembro de 2013, a divulgação dos assassinatos e atos cruéis com outros presos é realizada por meio de vídeos postados no canal YouTube ${ }^{49}$, e propagados por WhatsApp.

A rede social Facebook, em que se encontram páginas que seriam de "grupos organizados", como o PCC, que no ano de 2014 já tinha quase 400.000 curtidas $^{50}$, é usada para se apresentar à comunidade e difundir sua ideologia, mas, assim como para os demais usuários das redes

44 FOUCAULT, Michel. Vigiar e punir: nascimento da prisão. Trad. Raquel Ramalhete. 30a ed. Petrópolis: Vozes, 2005. p. 165-172. brasileiras ao tentar ganhar poder fora de São Paulo. Revista Piauí, n. 125, fev. 2017. p. 24.

48 Ver fotografias em: ADORNO, Sérgio; SALLA, Fernando. Criminalidade organizada nas prisões e os ataques do PCC. p. 11.

49 Ao inserir a expressão "chacina pedrinhas" num dos maiores buscadores da rede mundial de computadores aparecem mais de 24.000 resultados e os que se referem efetivamente, aos fatos ocorridos em dezembro de 2013, remetem a postagens de vídeo no canal Youtube. (Cf. <https://www.google.com.br/search?q=chacina+pedrinhas \&ie $=$ utf-8\&oe $=$ utf-8\&client $=$ firefox-b\&gws_rd=cr\&ei=1rvXWIntMsmYwgTSmLaoBQ>. Acesso em: 25 mar. 2017). CASTRO, Raimundo de. Fotos da Rebelião na Penitenciária de Pedrinhas em São Luís - MA. Castro Digital. 14 Nov. 2010. Disponível em: <http://www.castrodigital.com.br/2010/11/fotos-rebeliao-penitenciaria-pedrinhas.html>. Acesso em: 27 Mar. 2017.

50 MANSO, Bruno Paes. Página do PCC no Facebook já tem mais de 372 mil curtidas. Estadão, São Paulo, 19 mar. 2014. Disponível em: <http://sao-paulo. 
e mídias sociais, o aplicativo WhatsApp também se coloca agora como meio de vanguarda da comunicação em rede.

O uso do aplicativo do WhatsApp, associado com as postagens no canal YouTube e no Facebook, dá conta da validação por parte dos internos de que a sociedade contemporânea tem na violência um de seus dilemas sócio-políticos mais graves, em seu grau mais bárbaro, inclusive, na mutação da forma de matar ${ }^{51}$. Se nos descolarmos do locus do sistema carcerário e sua barbárie poderíamos facilmente lembrar, num marco muito próximo, de levantes nas redes sociais procurando imagens do estupro coletivo ocorrido no Rio de Janeiro, em maio de 2016, ou do cantor sertanejo cujo corpo se encontrava no Instituto MédicoLegal, em 2015. A advertência filosófica de que o grotesco convoca está muito presente na sociedade do mal-estar difuso onde a morte é só mais uma morte e o morto mais um número ${ }^{52}$.

A utilização da violência, como forma de se estabelecer e de se auto-afirmar no sistema carcerário, faz com que os "grupos organizados" usem celulares ${ }^{53}$ dentro das unidades para difundir sua ideologia. Os meios de comunicação externos mais modernos, como smartphones, redes e mídias sociais e aplicativos, também passam a ser usados no âmbito interno. Isso demonstra que eles dispõem desses mecanismos e tecnologias dentro das unidades prisionais, não fossem os armamentos, inclusive, metralhadoras, fuzis e armas brancas, até mesmo facões que também foram encontrados, segundo divulgado pela mídia, nos episódios de janeiro de $2017^{54}$.

estadao.com.br/blogs/sp-no-diva/pagina-do-pcc-no-facebook-ja-tem-mais-de-372-mil-curtidas/>. Acesso em: 27 Mar. 2017.

51 BIRMAN, Joel. O sujeito na contemporaneidade: espaço, dor e desalento na atualidade. Rio de Janeiro: Civilização Brasileira, 2012. p. 83-84.

52 BAUMAN, Zygmunt. O mal-estar da pós-modernidade. Trad. Mauro Gama e Cláudia Martinelli Gama. Rio de Janeiro: Jorge Zahar. 1998. p. 199.

53 Os aparelhos celulares encontrem-se em primeiro lugar dentre os produtos apreendidos dentro das unidades prisionais de São Paulo já há algum tempo: cf. DIAS, Camila Caldeira Nunes. Disciplina Controle Social e Punição: O entrecruzamento das redes de poder no espaço prisional. Revista Brasileira de Ciências Sociais, v. 29, n. 85, jun. 2014. p. 115.

54 Essas imagens foram amplamente divulgadas pela mídia televisionada e por meio da web, nos primeiros dias de janeiro de 2017 . 
A comprovação da inserção dos detentos nas redes sociais, mesmo quando presos, pelas fotografias e pelos vídeos compartilhados na internet demonstram a dificuldade das agências de controle penitenciário para o implemento de sistemas de bloqueio das redes de telefonia móvel nos arredores das unidades prisionais. A possibilidade de que o bloqueio de sinal eventualmente afete pessoas nas proximidades, as dúvidas quanto à real eficácia de tais sistemas, bem como a quem incumbe instalar e promover a manutenção de tais equipamentos são elementos que obstam a sua efetiva implementação e operacionalização $0^{55}$.

Não fosse isso, a própria ação coordenada das facções é elemento que impõe obstáculos ao bloqueio de redes de celulares no entorno das penitenciárias. Em 2016, segundo a mídia, circularam mensagens e áudios via redes sociais contendo ameaças de rebeliões e ações violentas nas ruas, caso fossem implementados, de fato, mecanismos bloqueadores de sinal em estados como o Ceará e o Rio Grande do Norte ${ }^{56}$.

Ao mesmo tempo em que as penitenciárias podem ser compreendidas como o depósito de gente indesejável da sociedade ${ }^{57}$, para cujos problemas e violências intrínsecas a preocupação social jamais se volta - um estado de ignorância e descaso pelo que lá acontece - parece surgir, a partir desse novo nicho de comunicação inaugurado pela massiva ampliação do acesso às redes sociais e aos aplicativos de comunicação digital instantânea, uma espetacularização da barbárie presente na realidade penitenciária.

55 Em agosto de 2016, o Plenário do Supremo Tribunal Federal julgou as ADIs $5356,5327,5253,4861$ e 3835, decidindo que a competência para legislar sobre o bloqueio do sinal de celulares em presídio é da União e não dos Estados, com isso várias leis estaduais foram declaradas inconstitucionais. Conferir: Somente a União pode legislar sobre bloqueadores de sinal de celular em presídios, decide STF. Disponível em: <http://www.stf.jus.br/portal/cms/ verNoticiaDetalhe.asp?idConteudo=322213>. Acesso em: 30 mar. 2017.

56 Conforme se verifica das seguintes reportagens: <http://g1.globo.com/rn/ rio-grande-do-norte/noticia/2016/07/presos-do-rn-ameacam-motins-contra-bloqueadores-de-celular-ouca-audios.html $>$ e <http://tribunadoceara. uol.com.br/noticias/segurancapublica/bloqueio-de-celulares-em-presidios-do-ceara-deve-ser-anulado-pelo-stf/>. Acesso em 28 mar. 2017.

57 BAUMAN, Zygmunt. Vidas Desperdiçadas. Trad. de Carlos Alberto Medeiros. Rio de Janeiro: Jorge Zahar Editor. 2005. p. 107-109. 
A visibilidade que hoje se tem daquilo que acontece dentro dos muros dos presídios não parece estar associada à preocupação com o direito das pessoas privadas de liberdade, mas sim a uma continuidade entre aquilo que acontece aqui fora e lá dentro. A espetacularização e a banalização da violência que parece marcar o mal-estar de nossa sociedade contemporânea.

Essa continuidade é representada pela propagação das fotos e dos vídeos produzidos no espaço prisional - mas não só, como já se disse, uma vez que também se propagam cenas de estupros coletivos, fotos íntimas e vídeos de exames de necropsia - a partir de smartphones que não estão restritos ao âmbito prisional.

O aumento da criminalidade ocorre em número e complexidade, tanto no modus operandi quanto nos sujeitos e organizações envolvidos, numa lógica explosiva e exponencial, rompendo os paradigmas lineares. A tecnologia, o controle, e a inteligência também passaram a servir ao ilícito, na mesma velocidade temporal. ${ }^{58}$

O lançamento do aplicativo de mídia social em 2009, chamado de WhatsApp, tem sido indicado como forma de revolução da comunicação. Dentre as ferramentas desse aplicativo, uma das que o diferenciou dos demais é a possibilidade de constituição de "grupos" nos quais é possível a interação entre seus membros, além de permitir a postagem de vídeos e áudios, ou seja, a reunião de uma rede de contatos que tem a possibilidade de receber simultaneamente mensagens a partir de um sinal de rede. Esse aplicativo de mídia social tem sido reconhecido como uma das ferramentas tecnológicas contemporâneas que revolucionou a comunicação em rede ${ }^{59}$, fato que, na linha do que pondera Lopes Junior

58 GIACOMOLLI, Nereu José. Qualidade do inquérito policial. In: AMBOS, Kai; MALARINO, Ezequiel; VASCONCELOS, Eneas Romero de (coord.). Polícia e Investigação no Brasil. Brasília: Gazeta Jurídica, 2016. p. 173.

59 Sobre isso, ver: SOUZA, Juliana Lopes de Almeida; ARAÚJO, Daniel Costa de; PAULA, Diego Alves de. Mídia social WhatsApp: uma análise sobre as interações sociais. Revista Alterjor, v. 11, n. 1, p. 131-165, maio 2015. Em especial, a apresentação da metodologia e dados coletados acerca dos usuários da mídia WhatsApp: p. 146-155. 
não parece deixar de fora os "grupos organizados", inclusive, para se contrapor a outros de seus adversários.

Essa perspectiva implica a rejeição de uma retórica, bastante mobilizada nos repertórios da mídia contemporânea, nas conversas do dia-a-dia e nas intervenções de governos e organismos internacionais, que cristaliza o crime organizado como um monstro monolítico, como se ele fosse sempre a expressão do oposto daquilo que se realiza nas transações sociais cotidianas. Obviamente, seguir essa senda analítica não significa negar a existência de referentes que autorizem a construção de narrativas focadas no grotesco e no demasiado estranho. Mas, e aí insinuo um pouco da tese que busco defender aqui, quanto mais nos aproximamos dos eventos sociais tidos como representativos do crime organizado, mais nos damos conta da sua banalidade. Uma banalidade da qual, não raro, os próprios atores procuram fugir construindo representações grandiosas de si mesmos e de seu universo. ${ }^{60}$

Do breve percurso pontuado aqui, verifica-se a superação do uso de recursos tradicionais para a prática de delitos, bem como para a organização e a difusão de atos, por facções criminosas. A mutação ocorrida externamente à prisão, quanto ao uso de meios tecnológicos cada vez mais avançados e potentes, também é percebida no interior das prisões.

\section{As VICISSITUdES DA INVESTIGAÇÃo CRIMINAL NOS CASOS DE REBELIÕES E CHACINAS OCORRIDAS NO SISTEMA CARCERÁRIO BRASILEIRO}

A investigação criminal será abordada tanto numa perspectiva político-criminal, acerca da posição das autoridades instituídas em dar atenção aos graves episódios ocorridos nas unidades prisionais, quanto numa perspectiva da dogmática processual penal em face da dificuldade de coleta de provas, considerando todo o cenário já descortinado como também a presença tanto do concurso de crimes quanto do concurso de pessoas.

${ }^{60}$ LOPES JUNIOR, Edmílson. As redes sociais do crime organizado: a perspectiva da nova sociologia econômica. p. 54. 
A investigação acerca da própria existência das facções, enquanto possível delito de organização criminosa, que pudesse ser enquadrado tipicamente na Lei de Organização Criminosa de 2013 (Lei $\mathrm{n}^{\circ} 12.850 / 2013$ ) é referida apenas de forma marginal, como subsídio da análise central dos crimes de homicídio protagonizados pelas facções.

Também cabe pontuar que a investigação criminal, ainda que seja necessário sempre lembrar dos próprios dilemas de sua natureza jurídica e definição terminológica ${ }^{61}$, quanto aos "seus objetivos, métodos e rotinas tem mudado profundamente ao longo da história" ${ }^{62}$ e assim para um campo de observação é imprescindível "compreender o contexto político, social e cultural no qual ela se insere" ${ }^{63}$. Ainda sobre a investigação criminal, em sentido abstrato, vale lembrar que ela ocupa no imaginário popular uma forma de oferta inicial de justiça e sequencial de aprisionamento de culpados, pois "o desejo por segurança, ordem, controle, pela administração de riscos e pelo contingenciamento de chances certamente está presente em qualquer cultura”. ${ }^{64}$.

O Brasil apresenta uma série de problemas, sobretudo, em casos emblemáticos que envolvem homicídios e outras violações de direitos humanos, motivo pelo qual há um histórico envolvendo a apresentação de casos perante a Corte Interamericana de Direitos Humanos que reconheceu tais problemas no âmbito internacio-

${ }^{61}$ LOPES JUNIOR, Edmílson. As redes sociais do crime organizado: a perspectiva da nova sociologia econômica; GLOECKNER, Ricardo Jacobsen; LOPES JÚNIOR, Aury. Investigação preliminar no processo penal. 5. ed. rev. atual. e ampl. São Paulo: Saraiva, 2013. p. 89-96.

62 COSTA, Arthur Trindade Maranhão; OLIVEIRA JUNIOR, Almir de. Novos padrões de investigação policial no Brasil. Sociedade e Estado. São Paulo, v. 29, n. 85, jun. 2014. p. 147.

63 COSTA, Arthur Trindade Maranhão; OLIVEIRA JUNIOR, Almir de. Novos padrões de investigação policial no Brasil. p. 147.

64 GARLAND, David. A Cultura do Controle: crime e ordem social na sociedade contemporânea. Trad. André Nascimento. Rio de Janeiro: Revan, 2008. Para uma compreensão ampla do fenômeno descrito por Garland, envolvendo essa nova atuação do direito penal: GARLAND, David. A Cultura do Controle: crime e ordem social na sociedade contemporânea. p. 413-430. 
nal ${ }^{65}$. Também, necessário registrar a existência de manifestações da mesma Corte, no tema específico do sistema carcerário, no caso de Urso Branco ${ }^{66}$, da Penitenciária Dr. Sebastião Martins Silveira ${ }^{67}$,

${ }_{65}$ GIACOMOLLI, Nereu José. Qualidade do inquérito policial. Polícia e Investigação no Brasil. p. 163-170.

${ }^{66}$ CORTE IDH. Resolução da Corte IDH de 18 jun. 02. Medidas Provisórias Solicitadas pela CIDH a respeito da República Federativa do Brasil - Caso Penitenciária Urso Branco, pg. 02. Disponível em: <http://www.corteidh.or.cr/docs/medidas/urso_se_01_portugues.pdf $>$. Acesso em: 30 set. 2016. CORTE IDH. Resolução da Corte IDH de 18 jun. 02. Medidas Provisórias Solicitadas pela CIDH a respeito da República Federativa do Brasil - Caso Penitenciária Urso Branco, pg. 06. Disponível em: $<$ http://www.corteidh.or.cr/docs/medidas/urso_se_02_portugues. pdf $>$. Acesso em: 30 set. 2016. CORTE IDH. Resolução da Corte IDH de 29 ago. 02. Estabelece Medidas Provisórias a respeito da República Federativa do Brasil - Caso Penitenciária Urso Branco, pg. 12. Disponível em: <http://www.corteidh.or.cr/docs/medidas/urso_se_02_portugues.pdf $>$. Acesso em: 30 set. 2016. No caso específico de Urso Branco, vale registrar a existência de uma série de medidas nos anos de 2004, 2005, 2008, 2009 e 2011.

67 CORTE IDH. Resolução da Corte IDH de 28 jul. 02. Solicitação de Medidas Provisórias apresentadas pela CIDH com respeito ao Brasil Caso das Pessoas Privadas de Liberdade na Penitenciária Dr. Sebastião Martins Silveira. Disponível em: <http://www.corteidh.or.cr/docs/medidas/araraquara_se_01_por.pdf > Acesso em: 30 set. 2016. CORTE IDH. Resolução da Corte IDH de 30 set. 06. Solicitação de Medidas Provisórias apresentadas pela CIDH com respeito ao Brasil - Caso das Pessoas Privadas de Liberdade na Penitenciária Dr. Sebastião Martins Silveira. Disponível em: <http://www.corteidh.or.cr/docs/medidas/araraquara_se_02_por.pdf $>$ Acesso em: 30 set. 2016. CORTE IDH. Resolução da Corte IDH de 10 jun. 08. Solicitação de Medidas Provisórias apresentadas pela CIDH com respeito ao Brasil - Caso das Pessoas Privadas de Liberdade na Penitenciária Dr. Sebastião Martins Silveira. Disponível em: <http://www.corteidh.or.cr/docs/medidas/araraquara_se_04_por. pdf > Acesso em: 30 set. 2016. CORTE IDH. Resolução da Corte IDH de 25 set. 08. Solicitação de Medidas Provisórias apresentadas pela CIDH com respeito ao Brasil - Caso das Pessoas Privadas de Liberdade na Penitenciária Dr. Sebastião Martins Silveira. Disponível em: <http:// www.corteidh.or.cr/docs/medidas/araraquara_se_05_por.pdf $>$ Acesso em: 30 set. 2016. 
Complexo Penitenciário Curado ${ }^{68}$, Pedrinhas ${ }^{69}$ e Instituto Penal Plácido de Sá Carvalho ${ }^{70}$.

Entretanto, a dramática situação do cárcere no país, com violação sistemática de direitos, parece ser difusa.

Corria o ano de 2008. Antes de o Conselho Nacional de Justiça, então sob a presidência do Ministro Gilmar Mendes, debruçar-se sobre o drama do cárcere no Brasil, o Conselho Nacional de Política Criminal fez uma série de relatórios sobre os principais presídios brasileiros. A situação era alarmante. No Espírito Santo, a Casa de Custódia de Viana e os presídios em contêineres motivaram um pedido de intervenção federal naquele Estado. $\mathrm{Na}$ visita à Penitenciária Lemos de Brito, logo após ser encontrado um detento com fratura exposta em pleno pátio, sem qualquer esboço de atendimento, o Governo da Bahia dispôs-se a fazer um Termo de Ajustamento de Conduta para sanar as irregularidades ali encontradas. No Recife, a Penitenciária Aníbal Bruno era

68 CORTE IDH. Resolução da Corte IDH de 22 mai. 14. Medidas Provisórias a respeito do Brasil - Assunto do Complexo Penitenciário de Curado. Disponível em: <http://www.corteidh.or.cr/docs/medidas/curado_se_01_por.pdf> Acesso em: 30 set. 2016. CORTE IDH. Resolução da Corte IDH de 07 out. 15. Medidas Provisórias a respeito do Brasil - Assunto do Complexo Penitenciário de Curado. Disponível em: <http://www.corteidh.or.cr/docs/medidas/curado_se_02_por.pdf> Acesso em: 30 set. 2016. CORTE IDH. Resolução da Corte IDH de 18 nov. 15. Medidas Provisórias a respeito do Brasil - Assunto do Complexo Penitenciário de Curado. Disponível em: <http://www.corteidh. or.cr/docs/medidas/curado_se_03_por.pdf> Acesso em: 30 set. 2016.

CORTE IDH. Resolução da Corte IDH de 14 nov. 14. Medidas Provisórias a respeito do Brasil - Assunto do Complexo Penitenciário de Pedrinhas. Disponível em: <http://www.corteidh.or.cr/docs/medidas/pedrinhas_ se_01_por.pdf > Acesso em: 30 set. 2016.

70 CORTE IDH. Resolução da Corte IDH de 13 fev. 17. Medidas Provisórias a respeito do Brasil - Assunto do Instituto Penal Plácido de Sá Carvalho. Disponível em: <http://www.corteidh.or.cr/docs/medidas/placido_se_01_ por.pdf >. Acesso em: 15 maio 2017. Na mesma data, 13 de fevereiro de 2017, foram reunidas as reclamações relativas a quatro unidades de detenção: CORTE IDH. Resolução da Corte IDH de 13 fev. 17. Medidas Provisórias a respeito do Brasil - Assunto da Unidade de Internação Socioeducativa, do Complexo Penitenciário de Curado, do Complexo Penitenciário de Pedrinhas, e do Instituto Penal Plácido de Sá Carvalho. Disponível em: <http://www. corteidh.or.cr/docs/medidas/asuntos_unidad_se_01_por.pdf $>$. Acesso em: 15 maio 2017. 
totalmente controlada pelos chaveiros, nomes que alguns presos recebiam por terem as chaves das celas. No encontro com o Governador Eduardo Campos, acordou-se a divisão do presídio, para facilitar sua administração. Em Porto Alegre, o Presídio Central, que fora construído para ser uma referência, estava em petição de miséria, totalmente desfigurado pela superpopulação carcerária e pela inexistência de grades em muitos raios. A Penitenciária de Urso Branco, em Porto Velho, palco do segundo maior massacre de presos depois do Carandiru, vinha sob uma gestão compartilhada (União e Estado de Rondônia) desde a recomendação da Corte Interamericana de Direitos Humanos. Muitos outros presídios preocupavam, quase sempre pela má ou inexistente - administração, dentre os quais o de Pedrinhas. ${ }^{71}$

A ocorrência de mortes do sistema penitenciário tem indicativo de sobretaxa em relação à população livre. Os dados do próprio órgão gestor do sistema penitenciário (o DEPEN Nacional) informam que o risco de morrer (de forma violenta, excluindo doenças e agravos de saúde) para quem está no sistema prisional é seis vezes maior em comparação com quem está em liberdade ${ }^{72}$.

De forma geral, não obstante a taxa de homicídios na população em geral ser bastante elevada no Brasil, colocando o país nos primeiros lugares, em recortes muito dramáticos, como o das mortes de crianças e adolescentes ${ }^{73}$, a investigação dos homicídios tem demonstrado uma taxa de esclarecimento absolutamente baixa.

O índice de elucidação dos crimes de homicídio é baixíssimo no Brasil. Estima-se, em pesquisas realizadas, inclusive a realizada pela Associação Brasileira de Criminalística, 2011, que varie entre $5 \%$ e $8 \%$. Este percentual é de $65 \%$ nos Estados Unidos, no Reino Unido é de $90 \%$ e na França é de $80 \%$.

71 CEGUEIRA deliberada estatal. Editorial. Boletim IBCCRIM.

72 Cf. BRASIL. Departamento Penitenciário Nacional. Levantamento nacional de informações penitenciárias Infopen: dezembro de 2014. Brasília: Infopen, 2016. p. 51-54. Disponível em: <http://s.conjur.com.br/dl/infopen-dez14. pdf>. Acesso em: 27 jan. 2017.

73 WAISELFISZ, Julio Jacobo. Mapa da Violência 2012 - Crianças e adolescentes do Brasil. FLACSO Brasil. p. 60. Disponível em: <http://www.mapadaviolencia.org.br/pdf2012/MapaViolencia2012_Criancas_e_Adolescentes.pdf >. 
Nos inquéritos de homicídio, a média nacional de denúncias está entre $5 \%$ a $8 \%$, enquanto nos inquéritos finalizados da Meta 2, a média é de $19 \%{ }^{74}$

A partir desses dados seria necessário ponderar a seletividade policial na investigação de homicídios que se inicia a partir da atuação no inquérito policial ${ }^{75}$, descortinado o cenário de evidente seletividade das investigações, dada a impossibilidade de cobrir todo o cômputo de delitos.

Em que pese, normalmente, os estudos - em especial da criminologia crítica - estejam associados a uma análise da seletividade penal a partir de critérios do autor ${ }^{76}$, aqui o que se revela é uma espécie de seletividade penal negativa a partir da condição da vítima. Ou seja, a inexistência de uma percuciente e dedicada investigação criminal nos casos de ocorrências da letalidade externa ao cárcere de pessoas envolvidas com o tráfico de drogas ${ }^{77}$ assume contornos ainda mais dramáticos e de maior evidência diante de mortes envolvendo essas mesmas pessoas enquanto presas, particularmente quando os assassinatos decorrem da disputa de poder entre facções.

Talvez se pudesse afirmar que a cifra oculta em casos tais é a hipérbole da expressão "bandido bom é bandido morto", especialmente quanto for "por outro bandido". Em termos mais claros, a questão que se apresenta é: qual o interesse em investigar a ocorrência das mortes nas circunstâncias concretas indicadas nesse texto.

74 Relatório Nacional da Execução da Meta 2: um diagnóstico da investigação de homicídios no país. Brasília: Conselho Nacional do Ministério Público, 2012. p. 22 e 43. Disponível em: <http://www.cnmp.gov.br/portal/images/ stories/Enasp/relatorio_enasp_FINAL.pdf $>$.

75 DIAS, Jorge de Figueiredo; ANDRADE, Manuel da Costa. Criminologia: O Homem Delinquente e a Sociedade Criminógena. $2^{\mathrm{a}}$. reimpressão. Coimbra: Coimbra Editora, 1997. p. 444.

76 ZAFFARONI, Eugenio Raúl. BATISTA, Nilo; et. al. Direito Penal Brasileiro: primeiro volume - Teoria Geral do Direito Penal. 4. ed. Rio de Janeiro: Revan, 2011. p. 46-51.

77 O desprezo a essas mortes está retratado em: ZACCONE, Orlando. Indignos de vida: a forma jurídica da política de extermínio de inimigos na cidade do Rio de Janeiro. Rio de Janeiro: Revan, 2015. 


\subsection{UMA NOTA DE NATUREZA POLÍTICO-CRIMINAL SOBRE AS INVESTIGAÇÕES DAS CHACINAS DE 2017}

Numa busca aberta na rede mundial de computadores sobre a investigação criminal a respeito das chacinas (suas causas, seus protagonistas, etc.), as primeiras notícias retornam indicando a exigência da ONU em promover tal medida ${ }^{78}$, mas, acerca das posições das autoridades públicas, as notícias são muito esparsas. Tais notícias, não raro remetem ao expediente tradicional da coleta de depoimentos de agentes penitenciários e de outros presos, cujas possibilidades de testemunho precisam ser compreendidas pela limitação da permanência no próprio presídio, além de prova de fidelidade e reações de vingança, e tantos outros entraves.

Diante desse fato, o diplomata Paulo Sérgio Pinheiro, reconhecido por sua pesquisa e produção na área de direitos humanos, atualmente vinculado à comissão independente da ONU para apurar as violações de direitos humanos na Síria, afirmou, em entrevista concedida à Deutsche Welle Brasil, que:

[...] não interessa ao atual governo, aos empresários e parlamentares comprados por organizações criminosas mudar essa situação. (...) O que acontece nas prisões é só a ponta do iceberg do tráfico de drogas, da lavagem de dinheiro e da impunidade generalizada em relação às organizações criminosas".

Em muitos estados, as facções fizeram acordos com o governo nas eleições e, depois, para impor a paz dentro dos presídios. Houve um acordo não escrito com esse circuito criminoso. Hoje, o temor do governo é que, como já está acontecendo, apareçam mais revoltas em outros estados. ${ }^{79}$

78 Ao digitar as expressões "investigação chacina presídios 2017" no buscador Google as primeiras notícias que retornam indicando a exigência de investigação têm uma chamada bastante parecida: Onu pede investigação imediata sobre presídio de Manaus. Acesso das notícias em: 09 Abr. 2017.

79 Entrevista Paulo Sérgio Pinheiro. Chacinas evidenciam conluio do Estado com facções. Disponível em: <https://www.cartacapital.com.br/sociedade/chacinas-evidenciam-conluio-do-estado-com-faccoes>. Acesso em: 09 abr. 2017. 
A posição do governo federal sobre os fatos contribuiu para uma série de críticas, desde a fala do Presidente da República de que o ocorrido foi um "acidente" 80 , passando pela polêmica manifestação do, à época, Secretário da Juventude, de que era 'preciso uma chacina por semana'81, até a criação de uma comissão especial, para tratar do sistema prisional. Importa registrar que a composição oficial do Conselho Nacional de Política Criminal e Penitenciária foi aumentada em mais oito vagas de nomeação exclusiva, seguida pela elaboração de um Plano de segurança pública, por parte do então Ministro da Justiça Alexandre de Moraes, que culminou na renúncia coletiva de diversos membros do colegiado oficial ${ }^{82}$.

\subsection{O RECURSO AOS MEIOS TRADICIONAIS DE INVESTIGAÇÃO CRIMINAL}

A abertura da investigação criminal no campus de análise desse texto parece encontrar, de início, um óbice de natureza temporal, dado que a comunicação da ocorrência dos delitos de homicídio, como no caso de 2017, em particular, é acompanhada da permanência de um motim instalado. Esse fato impede o acesso das autoridades públicas, seja para conter as violências que seguem sendo perpetradas, como para a realização de diligências de investigação, tais como a análise do local de crime e até mesmo para conseguir retirar os corpos e encaminhar para a perícia médico-legal ${ }^{83}$.

80 Temer afirma que chacina no presídio de Manaus foi 'acidente pavoroso'. Disponível em: <http://g1.globo.com/politica/noticia/temer-afirma-que-chacina-no-presidio-de-manaus-foi-acidente-pavoroso.ghtml >. Acesso em: 09 abr. 2017.

81 Secretário da Juventude de Temer diz que "tinha era que matar mais" nos presídios. Disponível em: <http://g1.globo.com/politica/noticia/secretario-da-juventude-de-temer-diz-que-tinha-era-que-matar-mais-nos-presidios.ghtml>. Acesso em: 09 abr. 2017.

82 Cúpula do Conselho Nacional de Política Penitenciária renuncia. Disponível em: <http://brasil.estadao.com.br/noticias/geral,cupula-do-conselho-nacional-de-politica-penitenciaria-renuncia-em-retaliacao-ao-ministro-da-justica,70001641216>. Acesso em: 09 Abr. 2017.

83 Sobre a situação, em particular, dos corpos no Complexo Anísio Jobim, vide o relato de Luís Carlos Valois: Espólio de medo, terror e desesperança. Boletim IBCCRIM. 
Nesse primeiro ponto, portanto, diversos elementos imprescindíveis para a investigação criminal começam a se dispersar comprometendo sua posterior eficácia, aqui compreendida como a de propiciar elementos de autoria e prova da materialidade. O starter da investigação criminal aqui já se coloca como prejudicado e pode pré-anunciar um resultado que compromete a um só tempo o índice de esclarecimento para fins processuais e a função simbólica de restabelecimento da paz abalada pelo crime ${ }^{84}$.

A ausência de um modelo ideal de investigação criminal, a volatilidade de seu glamour ${ }^{85}$ e a precariedade das condições do aparato policial, além da particular situação delineada, têm remetido episódios como esse ao marco tradicional da prova oral, com uma recursividade aos informantes e às testemunhas.

Num caso como o que está em análise é comum a utilização de informações obtidas junto aos agentes penitenciários e aos presos da unidade prisional tanto pelas autoridades penitenciárias quanto policiais. Os informantes, entretanto, ainda que sejam importantes para a investigação criminal não dispõem de uma regulamentação formal no Brasil, como também em diversos países.

Tal hiato contribui para uma série de críticas acerca das informações obtidas com essas pessoas, seja pela ausência de contraditório e ampla defesa, mas especialmente porque num caso como esse (o de briga de facções) pode existir - no que concerne em particular aos detentos - um favorecimento para um lado, com a concentração de informações sobre os rivais. Além das dificuldades sobre a veracidade da informação prestada e os favores que podem ser negociados para a prestação dessas informações. ${ }^{86}$ Cumpre lembrar que a própria Lei de Execução Penal admite a concessão de benesses, sem regulamentar, contudo, a forma e o motivo de tal, no qual podem ser cogitadas desde

84 GLOECKNER, Ricardo Jacobsen. LOPES JÚNIOR, Aury. Investigação preliminar no processo penal. p. 103-107.

85 COSTA, Arthur Trindade Maranhão; OLIVEIRA JUNIOR, Almir de. Novos padrões de investigação policial no Brasil. Sociedade e Estado. p. 148-150.

86 FONDEVILA, Gustavo Javier. Gestión y administración del sistema de informantes policiales en México. Sociológica (Méx.), México, v. 25, n. 72, p. 111137, abr. 2010. 
autorização para visita em dia não regulamentar até o perdão de faltas graves, mas podendo alcançar benesses que caracterizam delitos, como o uso de substância entorpecente no âmbito prisional.

Na mesma linha de uma investigação criminal com recursos tradicionais, aparece a questão da prova testemunhal ${ }^{87}$. Dentre várias questões que poderiam ser delineadas, como a precariedade do programa de proteção às testemunhas, verifica-se que a imposição do medo e do pavor pelas facções a partir dos próprios atos praticados - retomando o que já fora ponderado sobre a imposição de uma disciplina e a pretensão de hegemonia - tem como maior óbice à coleta de prova oral, com a inquirição das testemunhas. Fato recorrente quando se trata de casos que envolvem o crime organizado, em sentido mais amplo. ${ }^{88}$

É essencial para a sobrevivência da organização criminosa que ela impeça a descoberta dos crimes que pratica e dos membros que a compõem, principalmente dos seus líderes. Por isso ela atua de modo a evitar o encontro de fontes de prova de seus crimes: faz com que desapareçam os instrumentos utilizados para cometê-los e com que prevaleça a lei do silêncio entre os seus componentes; intimida testemunhas; rastreia por meio de tecnologias avançadas os locais onde se reúnem os seus membros para evitar interceptações ambientais; usa telefones e celulares de modo a dificultar a interceptação, preferindo conversar por meio de dialetos ou línguas menos conhecidas. ${ }^{89}$

No particular cenário das chacinas (mesmo das rebeliões), verifica-se que a colocação dos mais modernos (ainda que polêmicos)

87 Ainda que a doutrina pondere de que se poderia falar de prova testemunhal, somente quando produzida em juízo, aqui se está a ponderar, em sentido mais amplo, para identificar possíveis testemunhas que pudessem vir a figurar numa eventual denúncia. Sobre a prova testemunhal como a que de fato somente colhida perante o juízo, bem como seu conceito, características e classificações, conferir: BADARÓ, Gustavo Henrique. Processo Penal. 4. ed. rev. atual. e ampl. São Paulo: Revista dos Tribunais, 2016. p. 468-470.

MUÑOZ CONDE, Francisco. La búsqueda de la verdad en el proceso penal. 2. ed. Buenos Aires: Hammurabi, 2003. p. 56-57.

89 FERNANDES, Antonio Scarance. O equilíbrio entre a eficiência e o garantismo e o crime organizado. Revista Brasileira de Ciências Criminais, v. 16, n. 70, jan./fev. 2008. p. 245. 
meios de investigação sobre as organizações criminosas, mesmo em sua previsão ainda tímida da Lei 9.034/95, quanto da Lei 12.850/2013, parece deixar completamente de lado, inclusive, no uso do meio de prova mais recorrentemente comentado que é o da colaboração premiada ${ }^{90}$.

\subsection{O RECURSO AOS NOVOS MEIOS DE INVESTIGAÇÃO CRIMINAL}

Um dos pontos que pode ser indicado, no intuito de aprimorar a investigação criminal, é a superação do uso de metodologias arcaicas tendo em conta especialmente as novas realidades inseridas no paradigma tecnológico, particularmente na seara investigativa criminal ${ }^{11}$.

Não se podendo relevar o fato de que há uma considerável diferença entre uma concepção ideal de investigação e seu campo real de possibilidades, considerando a precariedade do cenário, que vai desde o armazenamento sobre dados gerais de investigação criminal no Brasil, quanto do próprio acesso a esses dados por meio de pesquisas sobre o seu modus operandi e o crime praticado, sendo - não raro - pouco confiáveis e raramente sistematizados ${ }^{92}$.

Tendo como premissa que as chacinas foram deflagradas, registradas e divulgadas por meio de celulares e smartphones - ainda que a fonte dessa informação seja a grande mídia, nos casos de 2013 e 2017 a discussão sobre a utilização de seu conteúdo na investigação criminal ganha especial consideração. Assim, a questão sobre acessar o conteúdo dos dispositivos móveis apreendidos e os dados nele armazenados torna-se central.

Verifica-se que, se de um lado, as autoridades policiais - nas corriqueiras (embora não menos polêmicas) abordagens de rua - sob o pretexto de coibir o tráfico de drogas - devassam celulares sem auto-

90 Pela amplitude das análises, inclusive, com trabalhos de direito comparado, consultar: MENDES, Soraia da Rosa. Editorial dossiê "Colaboração premiada e justiça criminal negocial”: novos e múltiplos olhares. Revista Brasileira de Direito Processual Penal. v. 03, n. 01, p. 31-38, jan./abr. 2017.

91 GIACOMOLLI, Nereu José. Qualidade do inquérito policial. Polícia e Investigação no Brasil. p. 173.

92 COSTA, Arthur Trindade Maranhão; OLIVEIRA JUNIOR, Almir de. Novos padrões de investigação policial no Brasil. Sociedade e Estado. p. 148. 
rização judicial, nos episódios acima, estando de posse de tais celulares poderia lançar mão de medidas legais e judiciais, para a coleta de elementos de prova sobre os fatos.

O julgamento do RHC 51.531-RO ${ }^{93}$, que ficou conhecido como paradigmático, em face da posição do Superior Tribunal de Justiça, afirmou que a busca pessoal de que resulte a apreensão de celular não dispensa a autorização judicial para o acesso de dados ${ }^{94}$.

No caso da investigação sobre as chacinas parece que a autoridade incumbida da investigação alcançaria - pela absoluta gravidade dos fatos com a morte de mais de 100 pessoas - a necessária decisão judicial para acessar os dados armazenados nos aparelhos apreendidos, especialmente às mídias produzidas, como fotos e vídeos, além das conversas por meio do WhatsApp, a fim de promover a apuração do ocorrido.

Não fosse o fato de que, segundo diversas fotografias divulgadas na internet, mesmo antes do episódio e até mesmo depois deles, internos aparecem fazendo uso constante e ostensivo de aparelhos celulares, que poderiam motivar inclusive decisões judiciais de interceptação telefônica.

Nesse ponto, parece se instalar um dos maiores dilemas propiciados pelo apelo à criminalização dos fatos praticados por organizações criminosas que é a necessidade de apuração de um lado e de outro a necessária e imprescindível observância dos direitos e garantias fundamentais do investigado ${ }^{95}$.

93 STJ. 6 ${ }^{\text {a }}$. Turma. Rel. Min. Néfi Cordeiro. RHC 51.531-RO. Penal. Processual Penal. Recurso Ordinário Em Habeas Corpus. Tráfico de Drogas. Nulidade da Prova. Ausência de Autorização Judicial para a Perícia no Celular. Constrangimento Ilegal Evidenciado. 1. Ilícita é a devassa de dados, bem como das conversas de whatsapp, obtidas diretamente pela polícia em celular apreendido no flagrante, sem prévia autorização judicial. 2. Recurso ordinário em habeas corpus provido, para declarar a nulidade das provas obtidas no celular do paciente sem autorização judicial, cujo produto deve ser desentranhado dos autos. (unânime, j. 19.04.2016).

ROSA, Alexandre Morais da; MARIEL, Danielle. O celular do preso em flagrante pode ser vasculhado? O caso do matador incauto e o STF. Em igual sentido: GARCIA, Rafael de Deus. Acesso a dados em celular exige autorização judicial. Nesse sentido são as observações de Diogo Malan, ainda que tratando das organizações criminosas no espectro econômico-financeiro: MALAN, Diogo. Notas sobre a investigação criminal e prova da criminalidade econômico-financeira organizada. Revista Brasileira de Direito Processual Penal, v. 2, p. 214-215, 2016. 
De todo modo, o aparato tecnológico colocado à disposição das autoridades investigativas exigiria outras providências, tais como a triangulação de sinais de rede, o cotejo entre conversas registradas em distintos dispositivos, bem como a compreensão do start de mensagens por meio de aplicativos, além da divulgação dos vídeos entre grupos e na rede.

\section{ConsideraçõEs finaIS}

A utilização de novas tecnologias de comunicação por parte da sociedade contemporânea apresenta-se, inclusive, no âmbito das prisões, com uma série de propósitos e finalidades até mesmo similares, além do compartilhamento de informações e dados entre o interior e o exterior das prisões.

A interação das ambiências externa e interna por meio das novas tecnologias, com especial referência à utilização de smartphones e mídias e redes sociais serve, também, a propósitos ilegais. Ainda que exista a proibição do ingresso de dispositivos móveis no sistema carcerário, a sua presença e utilização deixa marcas evidentes do fracasso da medida legal proibitiva.

A gestão paralela e não oficial das prisões pelas facções relacionadas diretamente com o comércio de drogas e os delitos correlatos vez ou outra reflui externamente, por meio de atos cruéis e violentos. As mazelas do sistema oficial demonstram o esfacelamento completo das justificativas teóricas da dogmática e da político-criminal sobre os fins da pena e as funções do direito penal, como também a falência do proibicionismo do comércio de drogas.

As mortes e as lesões corporais, que trazem consigo a investida de forma bárbara e cruel, cometidas por agentes públicos ou pelas próprias pessoas privadas de liberdade parecem restar absorvidas como "danos colaterais", mas não como sintoma de questões bem mais profundas sobre a gestão prisional.

A letargia em série histórica - com a ausência de investigação, sua frágil realização ou mesmo sua ocorrência tardia - permite a conclusão de que a chamada guerra às drogas e o combate ao crime organizado tem uma seletividade inata. Seletividade essa que segue orientada 
à persecução penal do "traficante da ponta”, aquele que está ali na rua e no comércio varejista de baixa potência, suscetível à prisão em flagrante e a apreensão e devassa não autorizada de seu celular. Seu ingresso nos presídios viabiliza o acesso à hiperestrutura do sistema, que o insere rapidamente num outro nível de criminalidade e de violência, ainda que mais letal e cruel, propiciada pela própria prisão.

Associada às questões de ordem político-criminal, no tema em análise, emergem problemas de ordem metodológica e científica na investigação criminal, além da carência de especialização das polícias para lidar com esse grupo de casos e da precariedade dos meios de investigação colocados à disposição das autoridades. Esses fatos são potencializados quando se está diante de casos que envolvem concurso de crimes e de pessoas quando se evidenciam as dificuldades de controle da deflagração e contenção dos crimes que acontecem em série e de forma continuada prejudicando, ou até mesmo inviabilizando, a investigação criminal.

\section{REFERÊNCIAS BIBLIOGRÁFICAS}

ADORNO, Sérgio; SALLA, Fernando. Criminalidade organizada nas prisões e os ataques do PCC. Estudos Avançados, São Paulo, v. 21, n. 61, p. 07-29, dez. 2007. https://doi.org/10.1590/s0103-40142007000300002

BADARÓ, Gustavo Henrique. Processo Penal. 4. ed. rev. atual. e ampl. São Paulo: Revista dos Tribunais, 2016.

BATISTA, Vera Malaguti. O medo e o método. Instituto Carioca de Criminologia. Discursos Sediciosos: Crime, Direito e Sociedade. Rio de Janeiro: Freitas Bastos Editora, ano 5, n. 9 e 10, p. 187-195, $1^{\circ}$ e $2^{\circ}$ semestres, 2000.

BAUMAN, Zygmunt. O mal-estar da pós-modernidade. Trad. Mauro Gama e Cláudia Martinelli Gama. Rio de Janeiro: Jorge Zahar. 1998.

BAUMAN, Zygmunt. Vidas Desperdiçadas. Trad. de Carlos Alberto Medeiros. Rio de Janeiro: Jorge Zahar Editor. 2005.

BIRMAN, Joel. O sujeito na contemporaneidade: espaço, dor e desalento na atualidade. Rio de Janeiro: Civilização Brasileira, 2012.

BITENCOURT, Cezar Roberto; BUSATO, Paulo César. Comentários à Lei de Organização Criminosa: Lei n. 12.850/2013. São Paulo: Saraiva, 2014.

BRASIL. Departamento Penitenciário Nacional. Levantamento nacional de informações penitenciárias Infopen: dezembro de 2014. Brasília: Infopen, 2016. p. 
51-54. Disponível em: <http://s.conjur.com.br/dl/infopen-dez14.pdf>. Acesso em: 27 jan. 2017.

CALDEIRA, Cesar. A política do cárcere duro: Bangu 1. São Paulo em Perspectiva, São Paulo, v. 18, n. 1, p. 87-102, mar. 2004.

CEGUEIRA deliberada estatal. Editorial. Boletim IBCCRIM, n. 255, fev. 2014.

COSTA, Arthur Trindade Maranhão; OLIVEIRA JUNIOR, Almir de. Novos padrões de investigação policial no Brasil. Sociedade e Estado. São Paulo, v. 29, n. 85, p. 113-127, jun. 2014. http://dx.doi.org/10.1590/S0102-69922016000100008

DIAS, Camila Caldeira Nunes. A disciplina do PCC: a importância do (auto) controle na sociabilidade prisional. Revista Brasileira de Ciências Criminais, v. 18, n. 86, p. 393-414, set./out. 2010.

DIAS, Camila Caldeira Nunes. Da pulverização ao monopólio da violência: expansão e consolidação do Primeiro Comando da Capital (PCC) no sistema carcerário paulista. 386 f. Tese (Doutorado em Sociologia) - Faculdade de Filosofia, Letras e Ciências Humanas, Universidade de São Paulo, São Paulo, 2011. https://doi.org/10.11606/t.8.2011.tde-13062012-164151

DIAS, Camila Caldeira Nunes. Disciplina Controle Social e Punição: O entrecruzamento das redes de poder no espaço prisional. Revista Brasileira de Ciências Sociais, v. 29, n. 85, p. 113-127, jun. 2014. http://dx.doi.org/10.1590/ S0102-69092014000200008

DIAS, Jorge de Figueiredo. A criminalidade organizada: do fenómeno ao conceito jurídico-penal. Revista Brasileira de Ciências Criminais, v. 16, n. 71, p. 11-30, mar./abr. 2008.

FERNANDES, Antonio Scarance. O equilíbrio entre a eficiência e o garantismo e o crime organizado. Revista Brasileira de Ciências Criminais, v. 16, n. 70, p. 229268, jan./fev. 2008.

FONDEVILA, Gustavo Javier. Gestión y administración del sistema de informantes policiales en México. Sociológica (Méx.), México, v. 25, n. 72, p. 111-137, abr. 2010.

FOUCAULT, Michel. Vigiar e punir: nascimento da prisão. Trad. Raquel Ramalhete. $30^{\mathrm{a}}$ ed. Petrópolis: Vozes, 2005.

GARCIA, Rafael de Deus. Acesso a dados em celular exige autorização judicial. Disponível em: <http://www.conjur.com.br/2017-fev-06/rafael-garcia-acessodados-celular-exige-autorizacao-judicial>. Acesso em: 02 abr. 2017.

GARLAND, David. A Cultura do Controle: crime e ordem social na sociedade contemporânea. Trad. André Nascimento. Rio de Janeiro: Revan, 2008. 
GIACOMOLLI, Nereu José. Qualidade do inquérito policial. In: AMBOS, Kai; MALARINO, Ezequiel; VASCONCELOS, Eneas Romero de (coord.). Polícia e Investigação no Brasil. Brasília: Gazeta Jurídica, 2016. p. 153-181.

GLOECKNER, Ricardo Jacobsen. LOPES JÚNIOR, Aury. Investigação preliminar no processo penal. 5. ed. rev. atual. e ampl. São Paulo: Saraiva, 2013.

GRECO FILHO, Vicente. Comentários à Lei de Organização Criminosa: Lei n. 12.850/13. São Paulo: Saraiva, 2014.

HASSEMER, Winfried. Persona, Mundo y Responsabilidad. Bases para una teoria de la imputación em Derecho Penal. Valencia: Tirant lo Blanch, 1999.

LOPES JÚNIOR, Edmílson. As redes sociais do crime organizado: a perspectiva da nova sociologia econômica. Revista brasileira de Ciências Sociais, São Paulo, v. 24, n. 69, p. 53-68, fev. 2009. http://dx.doi.org/10.1590/S010269092009000100004

LOURENÇO, Luiz Claudio; ALMEIDA, Odilza Lines de. "Quem mantém a ordem, quem cria desordem": gangues prisionais na Bahia. Tempo social - Revista de Sociologia da USP. São Paulo, v. 25, n. 1, p. 37-59, jun. 2013. http://dx.doi. org/10.1590/S0103-20702013000100003

MALAN, Diogo. Notas sobre a investigação e prova da criminalidade econômicofinanceira organizada. Revista Brasileira de Direito Processual Penal, Porto Alegre, vol. 2, n. 1, p. 213 - 238, 2016. http://dx.doi.org/10.22197/rbdpp.v2i1.22

MANSO, Bruno Paes. A Guerra: Como o PCC deflagrou uma crise nas prisões brasileiras ao tentar ganhar poder fora de São Paulo. Revista Piauí, n. 125, p. 2430, fev. 2017.

MENDES, Soraia R. Editorial dossiê "Colaboração premiada e justiça criminal negocial”: novos e múltiplos olhares. Revista Brasileira de Direito Processual Penal, Porto Alegre, vol. 3, n. 1, p. 31-38, jan./abr. 2017. https://doi.org/10.22197/ rbdpp.v3i1.56

MESQUITA NETO, Paulo de; SALLA, Fernando. Uma análise da crise de Segurança Pública de maio de 2006. Revista Brasileira de Ciência Criminais, v. 15, n. 68 , p. 309-351, set./ out. 2007.

MUÑOZ CONDE, Francisco. La búsqueda de la verdad en el proceso penal. 2. ed. Buenos Aires: Hammurabi, 2003.

NEDER, Gizlene. Cultura, poder e violência. Revista Latinoamericana de Psicopatologia Fundamental, São Paulo, v. 12, n. 1, p. 17-30, mar. 2009. https:// doi.org/10.1590/S1415-47142009000100002

PASTANA, Débora. Estado punitivo e encarceramento em massa: retratos do Brasil atual. Revista Brasileira de Ciências Criminais, v. 17, n. 77, p. 313-330, mar./abr. 2009. 
PPPs e terceirizações nos presídios: a indústria do sofrimento e da punição. Editorial. Boletim IBCCRIM, n. 279, fev. 2016.

RELATÓRIO Nacional da Execução da Meta 2: um diagnóstico da investigação de homicídios no país. Brasília: Conselho Nacional do Ministério Público, 2012. p. 22 e 43. Disponível em: <http://www.cnmp.gov.br/portal/images/stories/ Enasp/relatorio_enasp_FINAL.pdf>. Acesso em: 08 mai. 2017.

ROSA, Alexandre Morais da; MARIEL, Danielle. O celular do preso em flagrante pode ser vasculhado? O caso do matador incauto e o STF. Disponível em: $<$ http://emporiododireito.com.br/o-celular-do-preso-em-flagrante-pode-servasculhado-o-caso-do-matador-incauto-e-o-stf-por-alexandre-morais-da-rosae-danielle-mariel-heil/>. Acesso em: 02 abr. 2017.

RUDNICKI, Dani; SOUZA, Mônica Franco de. Em busca de uma política pública para os presídios brasileiros. As CPIS do sistema penitenciário de 1976 e 1993. Revista de Informação Legislativa. Brasília, a. 47, n. 186, p. 107-115, abr./ jun. 2010.

SALLA, Fernando. As rebeliões nas prisões: novos significados a partir da experiência brasileira. Sociologias, Porto Alegre, n. 16, p. 274-307, dez. 2006.

SOUZA, Juliana Lopes de Almeida; ARAÚJO, Daniel Costa de; PAULA, Diego Alves de. Mídia social WhatsApp: uma análise sobre as interações sociais. Revista Alterjor, v. 11, n. 1, p. 131-165, maio 2015.

VALOIS, Luís Carlos. Espólio de medo, terror e desesperança. Boletim IBCCRIM, n. 291, fev. 2017.

WAISELFISZ, Julio Jacobo. Mapa da Violência 2012 - Crianças e adolescentes do Brasil. FLACSO Brasil. Disponível em: < http://www.mapadaviolencia.org. br/pdf2012/MapaViolencia2012_Criancas_e_Adolescentes.pdf>. Acesso em: 10 mai. 2017.

ZACCONE, Orlando. Indignos de vida: a forma jurídica da política de extermínio de inimigos na cidade do Rio de Janeiro. Rio de Janeiro: Revan, 2015.

ZAFFARONI, Eugenio Raúl. BATISTA, Nilo; et. al. Direito Penal Brasileiro: primeiro volume - Teoria Geral do Direito Penal. 4. ed. Rio de Janeiro: Revan, 2011.

\section{FiLMES. DoCUMENTÁRIOS.}

Quase dois irmãos. Direção e produção Lúcia Murat. Brasil. 2004. Drama. DVD (102 min). Colorido.

Salve Geral. Direção Sérgio Rezende e Patrícia Andrade. Produção Joaquim Vaz de Carvalho. Brasil. 2009. Drama/Policial. DVD (119 min). Colorido. 
Tropa de Elite: missão dada é missão cumprida. Direção José Padilha. Produção Marcos Prado e José Padilha. Coprodução Eliana Soarez e James Darcy. Brasil. 2007. Ação. DVD (116 min.). Colorido.

Tropa de Elite 2: o inimigo agora é outro. Direção José Padilha. Produção Marcos Prado e José Padilha. Coprodução Wagner Moura e Bráulio Mantovani. Brasil. 2010. Ação. Blu-ray Disc (115 min.). Colorido.

\section{DADOS DO PROCESSO EDITORIAL}

(http://www.ibraspp.com.br/revista/index.php/RBDPP/about/editorialPolicies)

- Recebido em: 09/04/2017

- Controle preliminar e verificação de plágio: 10/04/2017

- Avaliação 1: 18/04/2017

- Avaliação 2: 22/04/2017

- Avaliação 3: 24/04/2017

- Avaliação 4: 24/04/2017

- Decisão editorial preliminar: 25/04/2017

- Retorno rodada de correções 1: 15/05/2017

- Decisão editorial 2: 17/05/2017

- Retorno rodada de correções 2: 17/05/2017

- Decisão editorial final: 18/05/2017

\section{Equipe editorial envolvida}

- Editor-chefe: 1 (VGV)

- Editor-associado: 1 (MMGV)

- Revisores: 4

\section{COMO CITAR ESTE ARTIGO:}

SÁ, Priscilla Placha. Questões político-criminais e processuais penais sobre a investigação criminal de chacinas protagonizadas por facções criminais nos presídios brasileiros. Revista Brasileira de Direito Processual Penal, Porto Alegre, vol. 3, n. 2, p. 567-604, mai./ago. 2017. https://doi.org/10.22197/rbdpp.v3i2.74

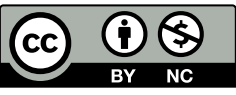

Esta obra está licenciada com uma Licença Creative Commons Atribuição-NãoComercial 4.0 Internacional. 